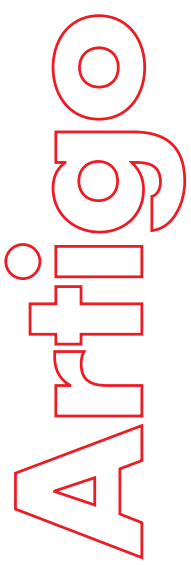

Revista

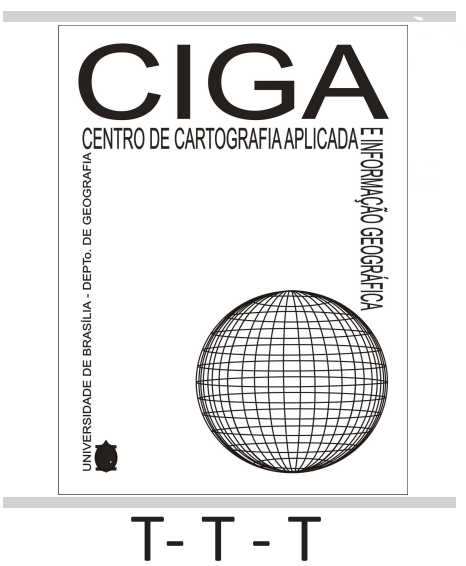

Revista Eletrônica: Tempo - Técnica - Território, V.11, N.1 (2020), 26:51 ISSN: 2177-4366

\section{ANÁLISE DIDÁTICA DAS RELACOES ETNICO- RACIAIS DO BRASIL AFRICANO NO LIVRO "GEOGRAFIA GERAL E DO BRASIL - ESPAÇO GEOGRAFICQ E GLOBALIZAÇĀO"}

\author{
Gustavo Silva Lyra
}

Como citar este artigo:

Lira, G. S.

ANÁLISE DIDÁTICA DAS RELAÇÕES ÉTNICO-RACIAIS DO BRASIL AFRICANO NO LIVRO “GEOGRAFIA GERAL E DO BRASIL - ESPAÇO GEOGRÁFICO E GLOBALIZAÇÃO - Revista Eletrônica: Tempo Técnica - Território, v.11, n.1 (2020),p.26:51 ISSN: 2177-4366.

Disponível em: http://periodicos.unb.br/index.php/ciga/

Este obra está licenciado com uma Licença Creative Commons Atribuição - Não Comercial 4.0 Internacional. 


\title{
ANÁLISE DIDÁTICA DAS RELAÇÕES ÉTNICO-RACIAIS DO BRASIL AFRICANO NO LIVRO “GEOGRAFIA GERAL E DO BRASIL - ESPAÇO GEOGRÁFICO E GLOBALIZAÇÃO”
}

\author{
Gustavo Silva Lyra \\ Graduando em Geografia pela Universidade de Brasília, Disciplina GEOAFRO - $1^{\circ}$ \\ Semestre 2020. E-mail: gustavolyra1@gmail.com
}

\begin{abstract}
RESUMO: A educação brasileira possui alguns instrumentos de regulamentação das matrizes educacionais a serem tratadas em sala de aula. O material que dá um maior suporte para o desenvolvimento das atividades em sala de aula é o livro didático, o qual também é regulamentado por um instrumento estatal especifico. Entende-se que o livro didático é engendrado por determinadas políticas estatais, sendo um instrumento que reflete os interesses de tal Estado. A tentativa de reverter o apagamento de determinadas realidades, em especial a questão étnico-racial da população afro-brasileira, foi incentivada no campo educacional a partir da Lei $n^{0} 10.639$, que obriga a implementação da discussão das relações étnico-raciais e do ensino de história e cultura afro-brasileira e africana. A análise do livro didático de Geografia parte do pressuposto da aplicação integral do aparato legal e busca compreender de que forma essa realidade é apresentada atualmente, em especial por se tratar de um campo do conhecimento que tem como um de seus pilares a compreensão do espaço, o qual é permeado de tensões, dentre estas, a questão racial.
\end{abstract}

Palavras-chave: Geografia, livro didático, Lei nº 10.639, discussão étnico-racial.

ABSTRACT: Brazilian education has some instruments for regulating educational matrices to be dealt with in the classroom. The material that provides the greatest support for the development of activities in the classroom is the textbook, which is also regulated by a specific state instrument. It is understood that the textbook is generated by certain state policies, being an instrument that reflects the interests of that state. The attempt to reverse the erasure of certain realities, especially the ethnic-racial issue of the AfroBrazilian population, was encouraged in the educational field as of Law No. 10,639, which requires the implementation of the discussion of ethnic-racial relations and the teaching of Afro-Brazilian and African history and culture. The analysis of the Geography textbook is based on the assumption of the full application of the legal apparatus and seeks to understand how this reality is currently presented, especially because it is a field of knowledge that has space understanding as one of its pillars, which is permeated by tensions, among them, the racial issue.

Keyword: Geography, textbook, Law n ${ }^{0} 10.639$, ethnic-racial discussion 


\section{INTRODUÇÃO}

A história do livro didático sempre esteve ligada a instituições governamentais e elites. Segundo Bairro (2009), um dos primeiros livros didáticos ocidentais que se têm notícia datam da época do Renascimento. Tratava-se do Manual de Hus, o qual apresentava uma ortografia padrão e era composto por frases religiosas as quais se iniciavam com letras diferentes e cujo conteúdo era voltado para a alfabetização popular. Analisar o livro didático como uma ferramenta ideológica é necessário pois, conforme Marques (2018), o livro didático institui uma leitura particular de mundo única, a qual é construída a partir de eixos temáticos regulamentados pelo Estado.

No Brasil, os livros didáticos são construídos a partir do Plano Nacional do Livro Didático (Santos, 2018), instrumento estatal que institui os eixos temáticos que devem ser trabalhados de acordo com os anos do sistema de ensino. Justamente por ser fruto de uma política de Estado, o livro didático acaba por ser tratado como o detentor da verdade universal, o que pode subverter a relação livro-professor, onde o livro acaba por ocupar o protagonismo em sala de aula (Marques, 2018). O modelo de escola no Brasil também reforça este papel pois coloca o livro didático como ferramenta indispensável para o funcionamento da instituição. (Santos, 2018)

Portanto, analisar o livro didático para além dos conteúdos expostos, na busca por compreendê-lo como objeto resultado de múltiplas disputas e negociações (Santos, 2018), é também um exercício de definição do projeto de educação que o Estado promove. Um dos temas relevantes para análise da condução da educação brasileira no espectro das temáticas postas como obrigatórias pelo PNDL e Matrizes Curriculares é a existência de um Brasil Africano e seus desdobramentos nos diversos âmbitos da sociedade. A presença ou não dessa temática se relaciona diretamente com os projetos hegemônicos de sociedade ocorridos no Brasil em diferentes períodos. Portanto, ao se inserir a existência de um Brasil Africano, possibilita-se a construção de uma concepção sobre o racismo existente "enquanto sistema de dominação em escala planetária, que historicamente se mundializa com dimensão do modo de produção capitalista” (Santos, 2018).

O Movimento Negro, pesquisadores e intelectuais na década de 80, protagonizaram uma reivindicação de um currículo nacional que refletisse de fato a realidade étnico-racial da sociedade brasileira. A marcha Zumbi contra o Racismo, pela 
Cidadania e a Vida, em 1995, protagonizou um momento de uma maior reivindicação, com propostas de políticas públicas voltadas para a população negra, inclusive no campo educacional, sugeridas para o governo federal. A partir desse processo, em 9 de janeiro de 2003, o então presidente, Luiz Inácio Lula da Silva, promulga a Lei $\mathrm{n}^{\circ}$ 10.639, alterando a Lei de Diretrizes e Bases da Educação Nacional Lei n ${ }^{\circ}$ 9.394/96, tornando obrigatório o ensino de cultura e história africana e afro-brasileira nos diferentes níveis educacionais. Com isso, homologa-se no dia 17 de junho de 2004 a instituição das Diretrizes Curriculares Nacionais para a Educação das Relações Étnico-Raciais e para o Ensino de História e Cultura Afro-Brasileira e Africana (MEC/SECADI, 2013).

“O parecer procura oferecer uma resposta, entre outras, na área da educação, à demanda da população afrodescendente, no sentido de políticas de ações afirmativas, isto é, sistemas de reparações, de reconhecimento e de valorização de sua história, cultura e identidade. Trata, ele, de política curricular, fundada em dimensões históricas, sociais, antropológicas oriundas da realidade brasileira, que busca combater o racismo e as discriminações que atingem particularmente os negros. Nessa perspectiva, propõe a divulgação e produção de conhecimentos, a formação de atitudes, posturas e valores que eduquem cidadãos orgulhosos de seu pertencimento étnico-racial. Assim, descendentes de africanos, povos indígenas, descendentes de europeus, de asiáticos terão a oportunidade de interagirem na construção de uma nação democrática, em que todos, igualmente, tenham seus direitos garantidos e sua identidade valorizada” (MEC/SICADI. 2013).

A partir desse marco legal, entende-se que, segundo (Santos, 2018), o "reposicionamento” do negro na educação, a partir da instituição do protagonismo de valores sociais, econômicos, culturais, históricos, bem como a exploração do racismo e de seus impactos sociais nos livros didáticos, promovem uma leitura positiva de pertencimento aos diferentes grupos, na busca de equidade representativa nas leituras de mundo apresentadas e trabalhadas. A partir disso, entende-se a importância de analisar o livro didático a partir da ótica da Lei $\mathrm{n}^{0} 10.639$ e de outras leituras à cerca da representatividade do contexto afro-brasileiro.

Nessa perspectiva, foi realizada a análise do livro didático de Geografia “Geografia Geral e do Brasil - Espaço Geográfico e Globalização”, volume voltado para 
o terceiro ano do Ensino Médio, de autoria de João Carlos Moreira e Eustáquio de Sene, sendo a $3^{\mathrm{a}}$ edição, do ano de 2016, publicado pela Editora Scipione (Figura 1).

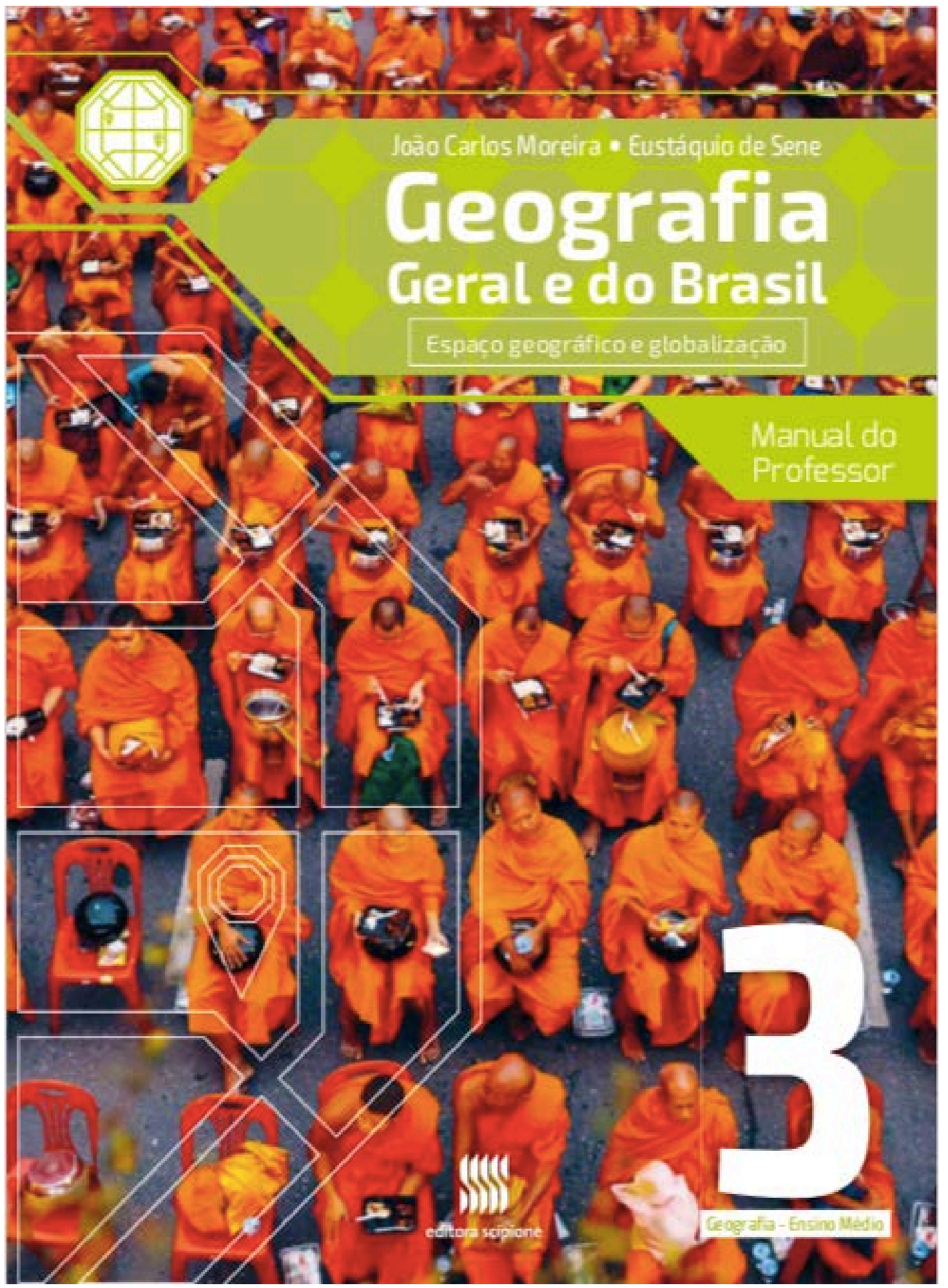

Figura 1: Capa do livro didático “Geografia geral e do Brasil - Espaço geográfico e globalização”. Fonte: Editora Scipione. 
1.1 Estrutura do livro didático e abordagem geográfica

Segundo o manual do professor do livro, a coleção é dividida em três volumes, correspondendo um para cada ano do Ensino Médio. O terceiro volume, o qual foi analisado, tem como temática a industrialização, os serviços e a política econômica no Brasil, a produção e consumo de energia, a geografia da população, o espaço urbano e o espaço agrário no Brasil e no mundo. Cada volume está dividido em unidades temáticas, as quais se desdobram em capítulos.

O manual traz ainda a explicitação de se utilizar de ferramentas visuais para complementar os textos dissertativos como forma de desenvolver e concatenar uma compreensão sobre o espaço geográfico e suas nuances, permitindo a elaboração de uma visão crítica deste. Além disso, há, segundo o manual, um cuidado em buscar diferentes recursos didáticos tais como matérias de jornais, sites, filmes, músicas, atlas, para enriquecerem o processo de aprendizado geográfico. A escolha de trabalhar com diversos elementos e de uma estrutura que segue uma sequência lógica parte da adoção teóricometodológica explicitada pelos autores no Manual do Professor, os quais se basearam em Ausubel (2013), que suspeitava a importância de uma estrutura cognitiva organizada como fator fundamental para que o aluno tenha interesse em aprender.

As unidades temáticas se dividem em capítulos, os quais se estruturam em tópicos, seguindo uma linearidade dos conteúdos (Figura 2). São comuns no corpo do texto seções tais como "Para saber mais e Outras leituras", a primeira com textos complementares dos próprios autores, e a segunda com produções de outros autores. Também são encontrados infográficos, os quais apresentam informações sobre um tema específico de uma maneira mais dinâmica, com fotos, textos e elementos visuais, estratégia visual adotada também em sínteses históricas. Determinadas temáticas, para serem melhor compreendidas, demandam uma contextualização histórica, logo, a seção “Síntese histórica” supre tal necessidade por meio de curtos textos, dados estatísticos, fotografias e demais ferramentas. 


\section{Sumário}

(1) Unidade 1: Brasil: indústria, política econômica e serviços

\begin{tabular}{|c|c|}
\hline CAPÍTUL01: A industrialização brasileira ....... 7 & CAPÍTULO 2: A economia brasileira após \\
\hline 1. Origens da industrialização & a abertura política \\
\hline $\begin{array}{l}\text { 2. O governo Vargas e a politica de "substituição } \\
\text { de importaçōes" }\end{array}$ & $\begin{array}{l}\text { 1. A aber tura comercial, a privatização e as } \\
\text { concessōes de serviços }\end{array}$ \\
\hline $\begin{array}{l}\text { Sintese histórica: Politica econômica e } \\
\text { industrialização bra sileira (1946-1964) .............. } 14\end{array}$ & $\begin{array}{l}\text { Sintese histórica: Politica econômica } \\
\text { brasileira de } 1992 \text { a } 2016\end{array}$ \\
\hline Pensando no Enem & 2. Estrutura e distribuição da indústria brasileira . \\
\hline $\begin{array}{l}\text { Dialogando com as disciplinas: } \\
\text { Os modernistas e o inicio da industrialização } \\
\text { em Săo Paulo }\end{array}$ & $\begin{array}{l}\text { Desconcentraçăo da atividade industrial, } 37 \\
\text { Pensando no Enem } \\
\text { 3. Estrutura e distribuiçăo espacial do comércio }\end{array}$ \\
\hline 3. Operiodo militar & e dos serviços \\
\hline Atividades ................. & Atividades \\
\hline & $\begin{array}{l}\text { Vestibulares de Norte a Sul } \\
\text { Caiu no Enem }\end{array}$ \\
\hline
\end{tabular}

Figura 2: Apresentação da estrutura do livro. Fonte: Editora Scipione, 2016.

No corpo do texto são encontrados ainda termos que constituem um Glossário do volume do livro didático, aproximando a temática trabalhada, que por vezes contém termos específicos, do aluno. Os termos estão sublinhados no decorrer do texto, e no final do volume, estão sumarizados em ordem alfabética com as respectivas sinopses. Encontra-se também a seção "Dialogando com as disciplinas”, numa tentativa de tratar temas de maneira interdisciplinar sempre com a Geografia inserido as discussões.

Percebe-se ao decorrer do livro o esforço em apresentar os espaços como construídos a partir de um contexto histórico, um produto da sociedade, na busca da compreensão das relações sociais que ocorrem no espaço, o qual é palco de tensões e contradições ,se aproximando a à leitura geográfica crítica (Campos, 2012). Tal abordagem se confirma no manual do professor, que explicita que "objeto de conhecimento da Geografia, a coleção ainda busca explicitar os processos que atuam sobre o território, entendido como espaço produzido e apropriado pelas sociedades humanas” (Moreira; Sene, 2016).

A primeira unidade trata da industrialização brasileira e introduz no início deste a necessidade do contexto histórico do espaço estudado para se compreender os processos ocorridos. Chama atenção a inserção de uma fala de Celso Furtado logo antes do texto de leitura complementar "Só um economista imagina que um problema de economia é estritamente econômico”, na busca do estímulo ao pensamento crítico. Traz também reflexões sobre o "milagre econômico" da ditadura militar, contrapondo a ideia 
apresentada pelo regime ditatorial da época, porém o enfoque maior recai no aspecto econômico, e tratando o social como um aspecto melhorado no Brasil na época, fruto de um processo acelerado de industrialização e urbanização, o qual acabou por gerar uma enorme dívida externa. Aborda ainda a economia do Brasil após abertura política pósditadura, ilustrando aspectos econômicos e políticos que possibilitaram a expansão comercial e industrial brasileira elencando os fatores que foram responsáveis pela distribuição geográfica industrial atual, bem como a sua diversidade.

A segunda unidade possui como temática "Energia e Meio Ambiente”. Trata da importância estratégica das fontes de energia para a economia, sociedade e meio ambiente, e introduz o uso de matrizes energéticas ecológicas, na busca pelo estímulo ao pensamento crítico, utilizando de ferramentas tais como leituras complementares. Apresenta a matriz energética brasileira e suas particularidades, como por exemplo, a sua diversidade de produção por diferentes meios.

A terceira unidade é intitulada "População". É levantada logo no início a necessidade de conhecer os indicadores sociais, econômicos, culturais e políticos para analisar as condições de vida de um povo, e que alguns desses dados revelam desigualdades entre grupos sócias, e traz uma leitura de que esse fenômeno da desigualdade atinge, em diferentes proporções, todas as nações do planeta. É apresentado um panorama da população mundial, com dados demográficos, uma breve discussão sobre religião, questão de gênero e direitos humanos básicos. É pincelada a relação entre população e economia através da apresentação dos conceitos de população economicamente ativa, distribuição de renda, bem como a relação de crescimento econômico e desenvolvimento social. São apresentadas as diferenças entre os conceitos de população e povo, nação e etnia. Os fluxos migratórios também compõem a estrutura da unidade e são trabalhados na escala global. Nesta unidade, há um capítulo dedicado para a estrutura população brasileira, com uma contextualização histórica e aspectos socioeconômicos desta.

A quarta unidade trata sobre o espaço urbano e os processos de urbanização, da escala global para a escala nacional. Sob a ótica mundial, é apresentada a forma com a qual os processos de urbanização tiveram início na civilização ocidental, através de um recorte histórico, e os problemas sociais atuais frutos deste processo. A articulação das cidades em seus diferentes níveis de influências e em como se organiza a rede mundial 
de cidades é um assunto trabalhado nesta unidade. A mesma lógica utilizada para apresentar a temática da unidade na ótica global é replicada para apresentar as particularidades dos processos urbanos ocorridos no Brasil.

Por fim, a quinta unidade aborda o espaço rural e a agropecuária. São apresentadas as modalidades agrícolas, bem como seus espaços de desenvolvimento. A Revolução Verde é introduzida no corpo do texto para a elaboração de uma discussão sobre o a população rural e o trabalhador agrícola, de uma forma geral. A produção orgânica e os alimentos transgênicos e a biotecnologia são explorados em um capítulo da unidade. Já numa análise de escala do Brasil, a unidade trabalha com aspectos tais como a modernização da produção agrícola, a diferença entre a produção familiar e empresarial as particularidades das relações de trabalho na zonal rural, a existência do Estatuto da Terra e a reforma agrária no Brasil. É também situada estatística e geograficamente a produção agropecuária atual no território nacional.

1.2 Apresentação e discussão de questões étnico-raciais da população afrodescendente no livro didático

Após análise das unidades e seus respectivos capítulos, foi possível observar de que forma o livro didático aborda determinadas questões étnico-raciais e como o seu conteúdo atende à obrigatoriedade da Lei 10.639 ou não. Num aspecto geral, nota-se que na maior parte dos capítulos e unidades, a questão étnico racial

Na primeira unidade, no primeiro capítulo, ao apresentar o cenário e os processos de industrialização e desenvolvimento econômico, em especial no Brasil, não foi observado um debate étnico-racial, ou ainda socioeconômico. São apontados, em sua maioria, aspectos econômicos, e os debates sociais são introduzidos de uma forma rasa, se resumindo a uma breve descrição das conquistas advindas da Constituição promulgada durante o governo de Getúlio Vargas, a qual instituía novos direitos trabalhistas. Em um tópico “Outras leituras” (Figura 3) intitulada “As distorções do ‘milagre brasileiro”” é abordado o crescimento da população marginalizada, trazendo dados sobre o crescimento de favelas em três capitais brasileiras, mas não se desenvolve uma discussão crítica sobre os dados apresentados. O tópico é seguido de uma figura de uma favela na cidade de São Paulo na década de 70. 


\section{Outras leituras 冈ि}

\section{As distorções do "milagre brasileiro"}

Concomitante ao "paraiso de consumo" que se abria para a classe média dos grandes centros urbanos, onde proliferavam supermercados, shoppings e os outdoors de construtoras oferecendo inúmeros lançamentos de apartamentos de luxo, crescia também a população marginalizada e miserável. A população favelada de Porto Alegre elevou-se de 30 mil pessoas em 1968 para 300 mil em 1980; a do Rio de Janeiro, de 450 mil em 1965 para 1,8 milhão em 1980; e a de São Paulo, de 42 mil em 1972 para mais de um milhão em 1980.

REZENDE FILHO, Cyro de Barros. Economia brasilejra contemporànea. Sào Paulo Contexto, 1999 p. 140 . (Manuais)

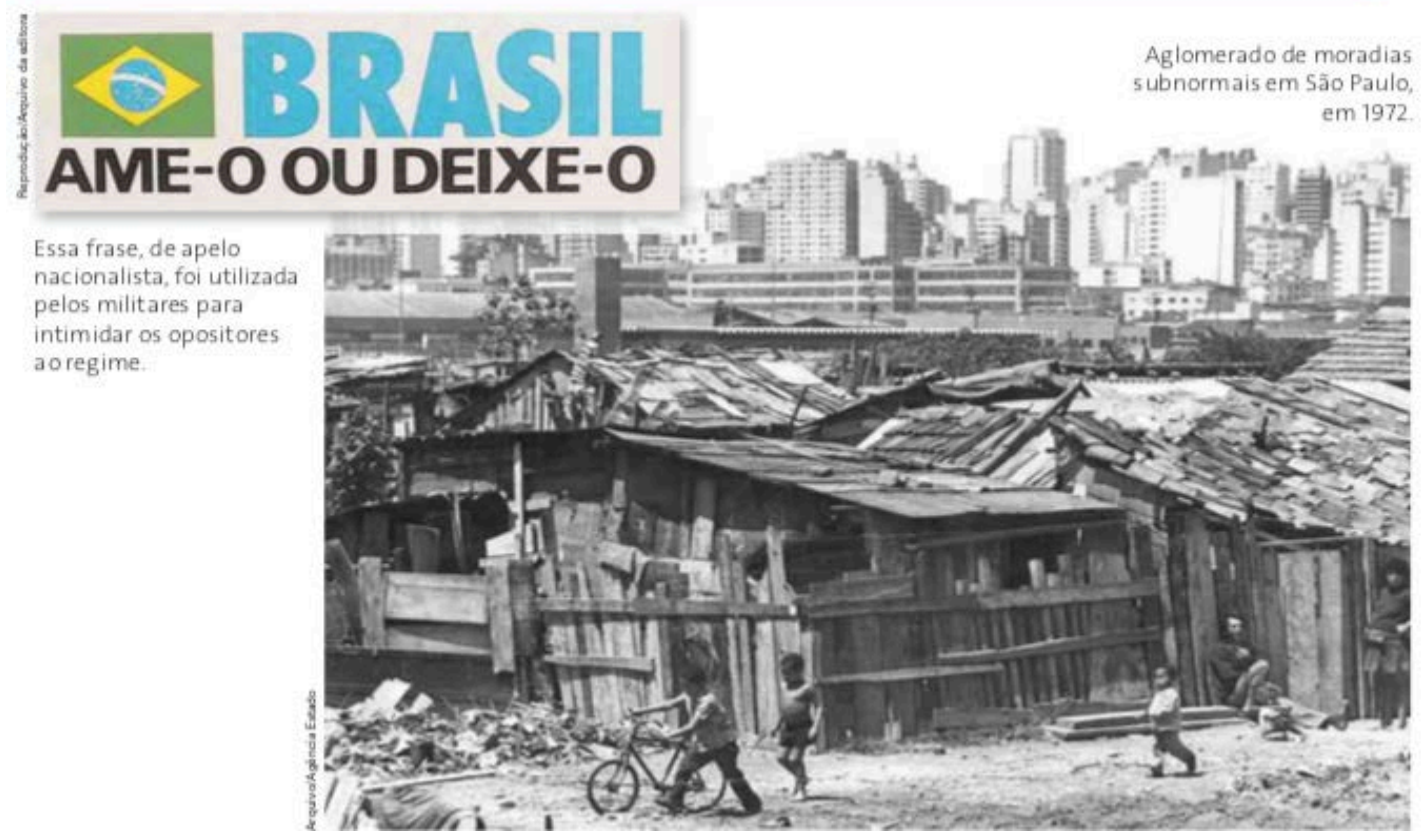

Figura 3: Seção “Outras leituras” e imagem de uma favela em São Paulo na década de 70. Fonte: Editora Scipione, 2016.

O fenômeno inflacionário ocorrido durante a ditadura militar, no qual os salários não eram reajustados seguindo a inflação vigente, causando uma diminuição do poder de compra das populações mais vulneráveis, também é introduzido na discussão do capítulo, porém não é feito um recorte social dessa população vulnerável. Os dados são tratados como unicamente estatísticos. Os movimentos populares trabalhistas e de reivindicação de eleições diretas são demonstrados apenas por duas ilustrações, e não há menção desses movimentos no corpo principal do texto (Figuras 4 e 5). 


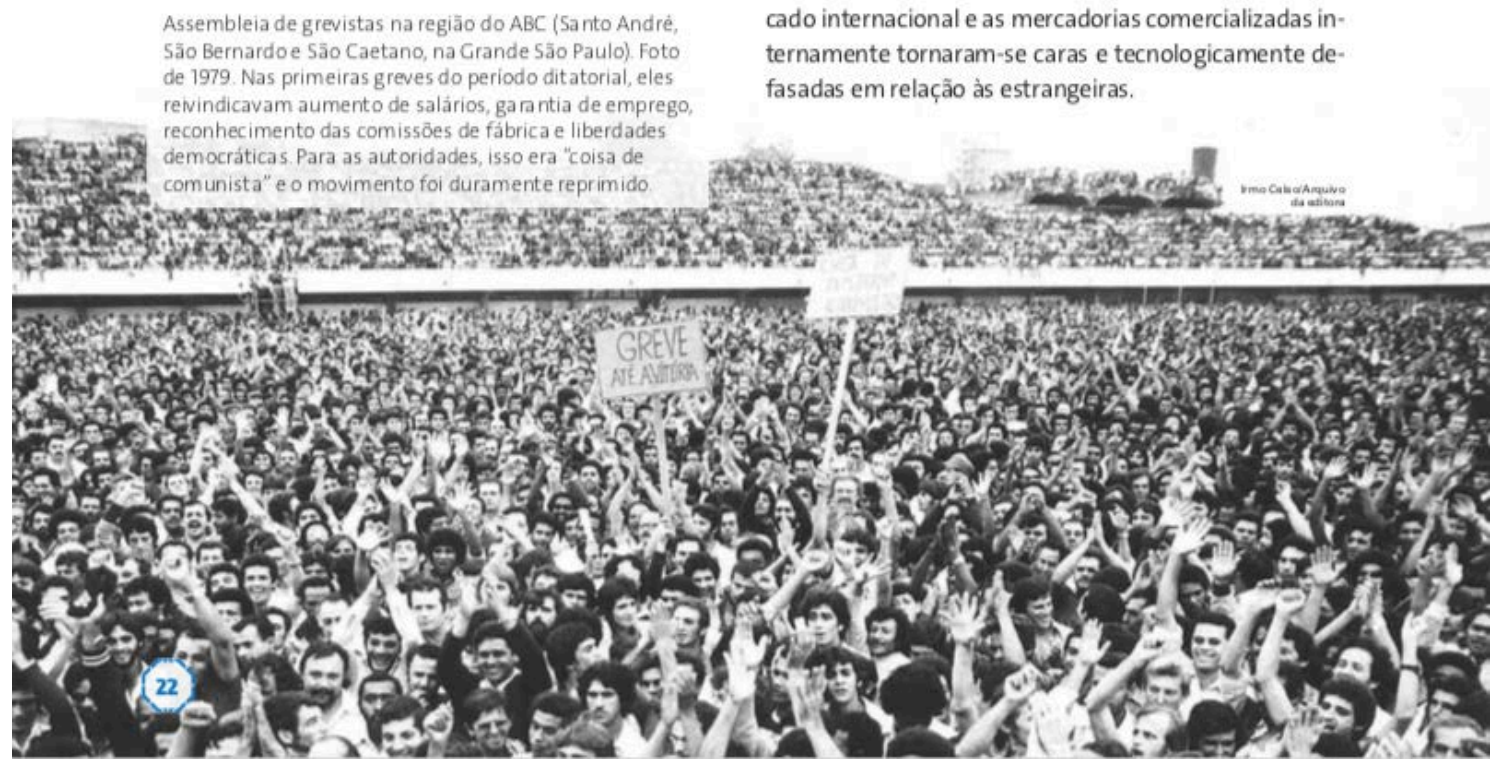

Figura 4: Foto de uma assembleia de grevistas na região do ABC no final da década de 70. Fonte: Editora

Scipione, 2016.

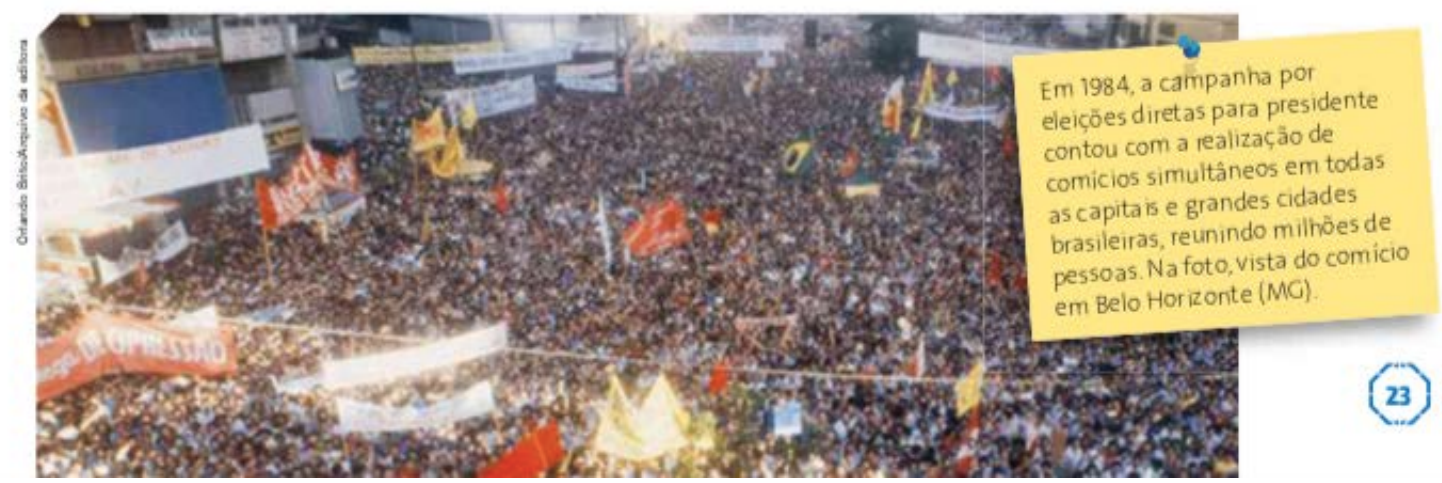

Figura 5: Foto de uma das campanhas do movimento que exigia eleições diretas no final da Ditadura militar em 1984. Fonte: Editora Scipione, 2016.

No segundo capítulo, a política adotada no período da abertura comercial ocorrida nos 80, cujos preços aumentavam diariamente por conta da inflação galopante, colocando os aspectos econômicos do desenvolvimento do parque industrial e do setor de comunicações no país em primeiro plano. Na seção "Para saber mais”, um texto sobre a relação entre a concentração de renda e a inflação é inserido, porém não há uma discussão socioeconômica desse evento.

Na segunda unidade, ao trata da matriz energética brasileira, alguns debates sociais poderiam ser introduzidos, em especial no que se refere às usinas hidrelétricas. 
Atualmente, esse debate se faz necessário devido ao racismo ambiental o qual populações tradicionais estão sujeitas durante e após as grandes obras das usinas hidrelétricas. As comunidades quilombolas figuram entre as comunidades tradicionais, e estão sujeitas à tal processo racista, como ocorre hoje no noroeste goiano, onde a possível construção de uma usina hidrelétrica ameaça a comunidade Kalunga, o maior território quilombola do país, por não levar em consideração o território delimitado da comunidade quilombola, bem como a importância do rio para a comunidade (Paulo, 2019).

A terceira unidade, a qual trata sobre população, é a que mais se observa um debate étnico-racial, atrelando este a detalhes socioeconômicos. Os aspectos estruturais da população são apresentados. Ao definir nação, o conceito é apresentado e trabalhado em seu sentido antropológico, tratado como um sinônimo de etnia, na definição de um grupo de pessoas que compartilham uma história comum e vivencia um padrão cultural o qual confere uma identidade coletiva. Logo, os autores do livro entendem que existem populações de determinado país que podem conviver com diferentes nações, ou etnias, sendo países multiétnicos, ou multinacionais. Os autores afirmam que, mesmo que uma ou demais nações estejam em consonância, a ação do Estado é necessária para mediar conflitos de interesses.

É trazido também a questão de gênero, porém também não há recorte étnico-racial na discussão. É uma questão delicada trabalhar a questão de gênero e não utilizar um recorte racial, e tal movimento epistêmico advém do começo das discussões feministas. Segundo Hooks (2015) “a recusa feminista, no passado, a chamar atenção para hierarquias sociais e as atacar, suprimiu a conexão entre raça e classe”. A ausência de uma discussão étnico-racial se torna mais evidente ao apresentar um mapa de paridade de gênero (Figura 6), no qual os países assinalados como mais desiguais possuem uma problemática histórica e socioeconômica que perpassa pela questão racial. 


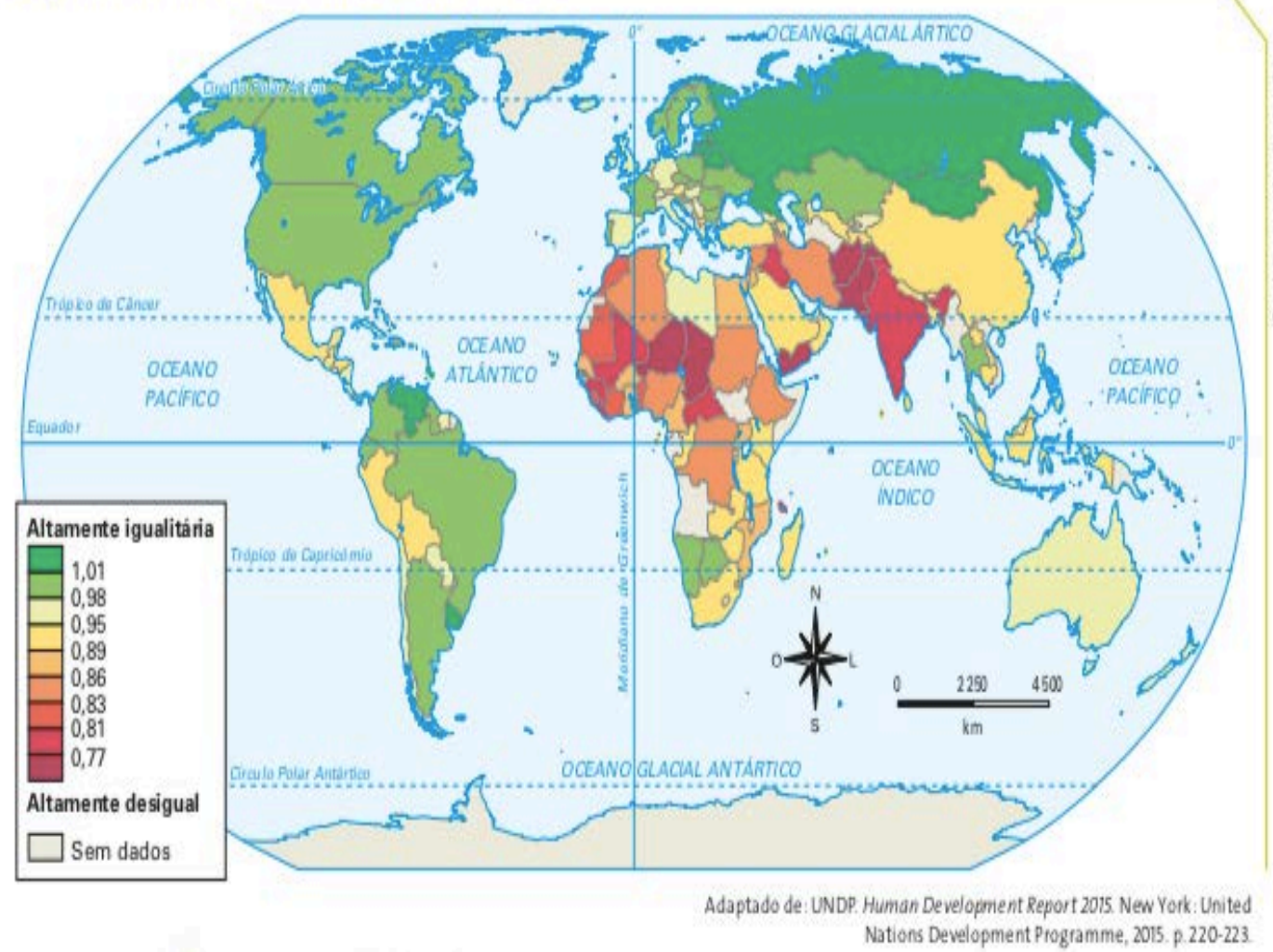

Figura 6: Mapa mundial com o índice de paridade de gênero em 2014. Fonte: Editora Scipione, 2016.

Tal discussão também não foi levantado no tópico “Reposição da população”, o qual insere uma tabela das taxas de crescimento da população e de fecundidade e uma foto (Figura 7) num contexto o qual também não se leva em consideração um recorte étnico-racial e socioeconômico. Apresentar os motivos para as altas taxas de crescimento populacional e de fecundidade, em especial nos países africanos, faz com que o pensamento crítico seja estimulado, principalmente por se tratar de um assunto que se relaciona à falta de acesso a serviços básicos de saúde. 


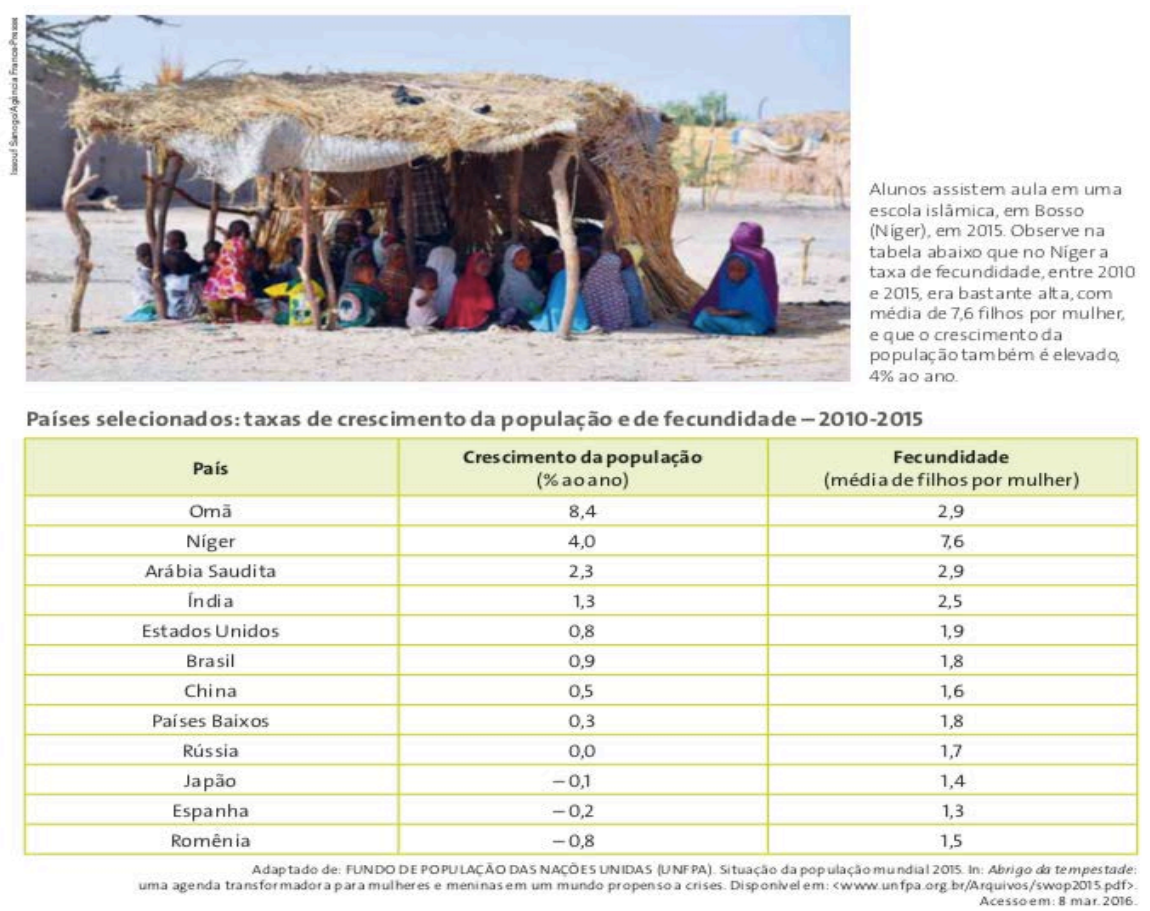

Figura 7: Foto de alunos numa escola em Níger e tabela com taxas de crescimento da população e de fecundidade entre 2010 e 2015. Fonte: Editora Scipione, 2016.

O capítulo que aborda os movimentos migratórios internacionais também carece de uma discussão histórica e étnico-racial, pois trata em primeiro plano as motivações econômicas para explicar a dinâmica dos fluxos migratórios. As demais motivações, tais como perseguição religiosa, guerras civis e regimes governamentais opressores, são apenas citados num tópico, não sendo desenvolvidos.

Os dados que ilustram a estrutura da população são inseridos nessa altura da apresentação dos temas discutidos no livro, um pouco deslocados. Julga-se que os inserir no início livro seria mais proveitoso pois embasaria uma discussão mais completa de determinados fenômenos observados no atual cenário mundial.

O capítulo "Formação e diversidade cultural da população brasileira” traz alguns aspectos étnico-culturais da população, estando de acordo com a Lei no 10.639 . Se inicia com uma discussão sobre a inexistência de dados sobre a população original do território indígena que viria a se tornar Brasil. São apresentados alguns aspectos históricos da colonização portuguesa, é citado o genocídio e etnocídio advindo desse processo e é explanado o aparato legal de proteção dos povos indígenas no Brasil atual, construídos numa tentativa de assegurar o direito dos indígenas em suas terras originais. 
Logo em seguida, a vinda de africanos escravizados para o território brasileiro a partir de 1532 é introduzida na discussão da formação da população brasileira, a qual é finalizada com a vinda de imigrantes europeus, asiáticos e latino-americanos após 1870, compondo o espectro étnico-racial que compõe a população brasileira.

É interessante notar a forma com a qual o tópico "Como se identifica a população brasileira” é construído. Utilizando dados do IBGE, apresentados em formato de gráfico (Figura 8), o tópico indica a queda no número de pessoas que se autoidentificam como brancas entre 1950 e 1980, porém voltou a crescer em 2010. A autoidentificação como parda é demonstrada como em crescimento desde 1950, podendo indicar, segundo os autores, um processo de aceitação e valorização de uma identidade afrodescendente por parte da população brasileira nas últimas décadas. A discussão se enriquece a partir do momento que os autores inserem a discussão da forma com a qual os dados podem ser colhidos e interpretados, citando o conceito de raça que o IBGE adota e suas categorias de heteroidentificação (branca, preta, amarela, parda e indígena, sendo essa inserida apenas no censo de 2010).

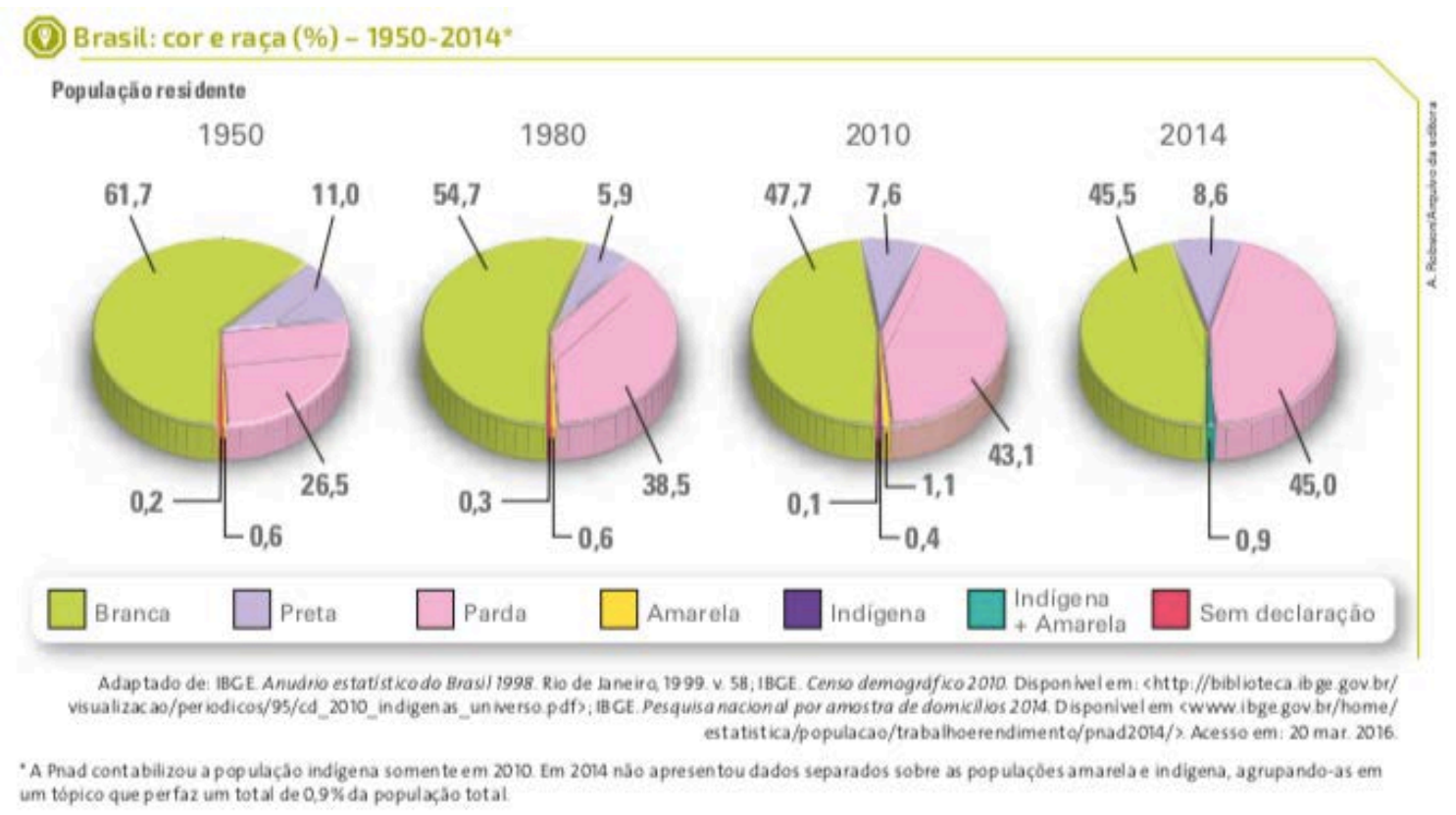

Figura 8: Gráficos ilustrativos das declarações de cor e raça nos diferentes Censos realizados pelo IBGE.

Fonte: Editora Scipione, 2016.

Tal tópico é seguido pela seção “Outras leituras”, a qual traz um texto intitulado “raça, cor e racismo: algumas conceituações necessárias”. Apesar de o texto apresentar um conteúdo elucidativo, abordando o racismo com tópicos enriquecedores para uma discussão, como o fato de o racismo ser um artifício teórico e utilizado como ferramenta 
para a promoção de uma exclusão social, entende-se que a temática poderia ser inserida no corpo principal do texto, se aproximando da leitura geográfica que os autores afirmam se utilizar, de uma geografia crítica, ao invés de ser apresentado como leitura complementar.

O tópico seguinte trata sobre a imigração internacional. Apresenta-se a discussão da falta de dados oficiais sobre o número de africanos que chegaram no país em situação de escravidão, vindos numa política de imigração forçada. Apesar de os africanos escravizados comporem a maior parte dos imigrantes no Brasil, há um maior espaço no corpo do texto para as correntes imigratórias livres. Também são apresentadas as atuais correntes de migração que tem como destino o Brasil. Na tentativa de ilustrar a situação atual dos imigrantes no Brasil, foi observado um erro na representação destes. A Figura 9, em teoria, ilustra os vencedores da Copa dos Refugiados do ano de 2014, ocorrida na cidade de São Paulo.

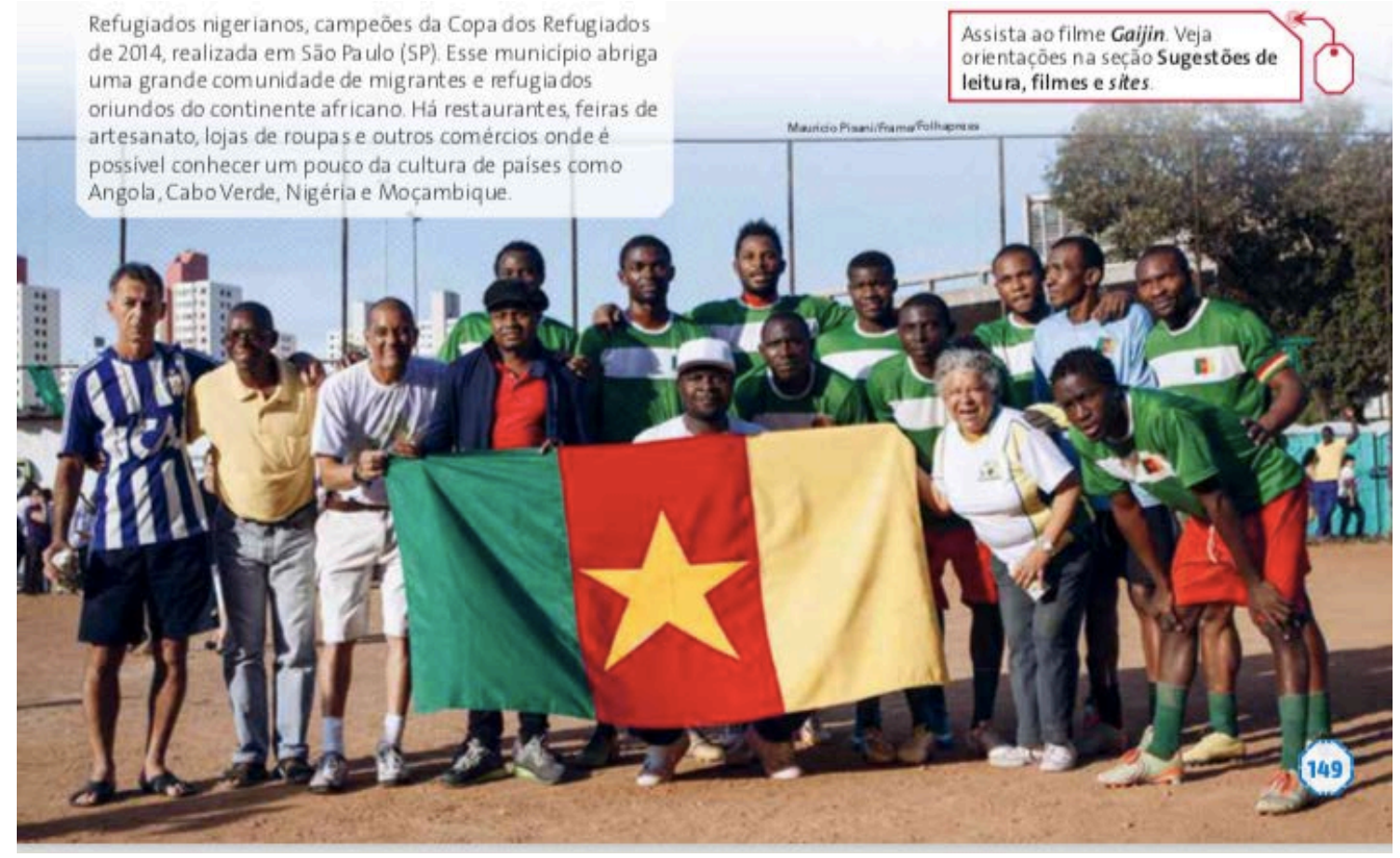

Figura 9: Tentativa de representação da seleção nigeriana na Copa dos Refugiados de 2014. Fonte: Editora Scipione, 2016.

Após uma busca sobre a Copa de Refugiados de 2014, encontrou-se a informação que, na verdade, os vencedores desta edição do torneio foram os haitianos, que jogaram contra os congoleses. Os nigerianos não chegaram nem às quartas de final (Mantovani, 2014). Não bastasse, na foto inserida no livro didático apresenta a delegação de 
Camarões, segurando sua bandeira oficial (Figura 10), e não a seleção nigeriana, que possui uma bandeira diferente (Figura 11) da República dos Camarões.
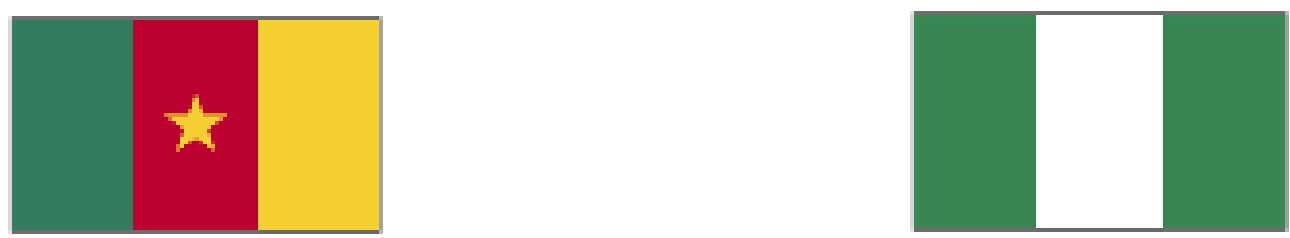

Figura 10: Bandeira da República de Camarões. Fonte: Ministério das Relações Exteriores, 2021

Figura 11: Bandeira da República Federal da Nigéria. Fonte: Ministério das Relações Exteriores, 2021.

Logo em seguida, são apresentados os dados de migração interna e de emigração, com um mapa ilustrando os fluxos migratórios. Esses movimentos são ilustrados como associados, desde o século XVI, a fatores econômicos, os quais baseiam esse fluxo nos dias atuais. Mais uma vez, o recorte socioeconômico não é utilizado para dar embasamento aos fluxos migratórios, os quais são determinantes para a ocorrência de tais fluxos.

O capítulo seguinte trata do crescimento vegetativo da população. As imagens escolhidas para escolher trazem informações importantes para a análise do evento. Ao se comparar as diferentes taxas de fecundidade com o passar dos anos, são utilizadas duas fotografias (Figura 12) de diferentes contextos sociais. Os traços fenotípicos da primeira ilustração, que apresenta uma família com uma taxa de fecundidade maior, é diferente da segunda imagem, que busca ilustrar uma taxa de fecundidade menor. 


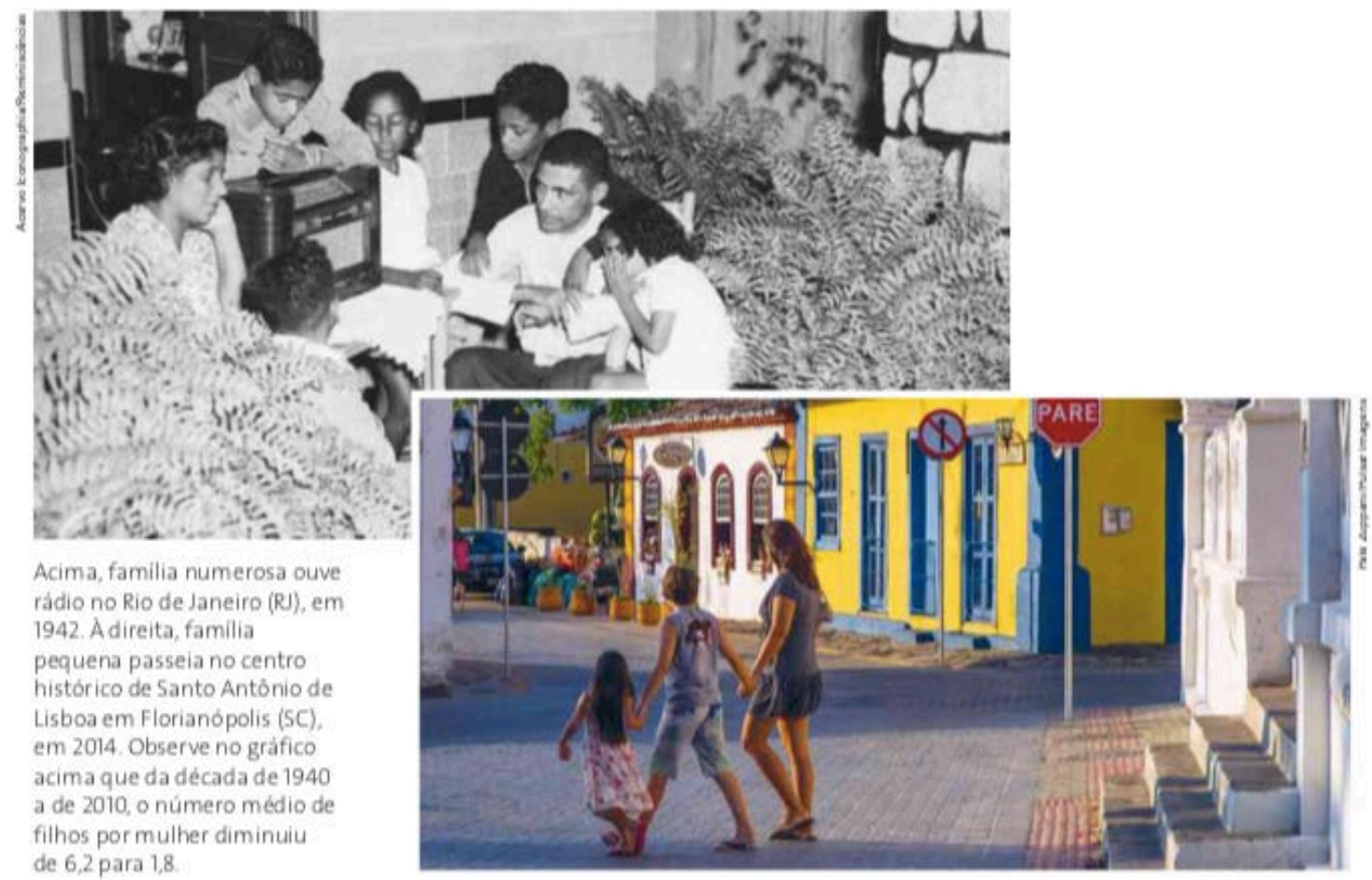

Figura 12: Representação de diferentes momentos históricos no Brasil relacionados à taxa de fecundidade. Fonte: Editora Scipione, 2016.

As pirâmides etárias do Brasil são inseridas na discussão das particularidades da população brasileira. É possível inferir que o estreitamento da base e o alargamento da porção mediana e o crescimento do topo está ligado a uma melhoria da qualidade de vida no país, mas não há um debate socioeconômico e étnico-social dos estratos populacionais que foram contemplados pela evolução da infraestrutura nacional que permitiu uma melhoria nesses índices.

O tópico seguinte contempla a população economicamente ativa e a distribuição de renda no Brasil. Após tal discussão, é inserido no corpo do texto o tópico “participação dos afrodescendentes”, que busca trazer a discussão da importância de se levar em consideração a distribuição de riquezas no país, logo, insere dois gráficos, os quais tratam do rendimento médio mensal por cor ou raça, e um gráfico de frequência escolar de pessoas de 15 a 17 anos por cor ou raça. Em seguida à apresentação de tais dados, no tópico “desigualdade social”, são levantados alguns dos motivos da problemática da desigualdade de assola o país, tais como a herança histórica da escravidão e a concentração de terras, as quais foram determinantes para determinados fluxos migratórios e para determinados processos irregulares de urbanização em grandes cidades brasileiras. Os Índices de Desenvolvimento Urbanos dos estados brasileiros (Figura 13) 
é apresentado logo após a discussão da desigualdade social, porém não são apontadas questões históricas e étnico-raciais que dão subsídio a tais índices. Os menores índices de desenvolvimento humano são encontrados em estados que possuem uma história escravagista secular no cenário nacional, a qual os menores índices correspondem à estados da região Nordeste.

Brasil: classificação das unidades da federação segundo o IDHM - 1991, 2000, 2010

\begin{tabular}{|c|c|c|c|c|c|c|c|}
\hline Posição/UF & $\begin{array}{c}\text { IDHM } \\
1991\end{array}$ & $\begin{array}{c}\text { IDHM } \\
2000\end{array}$ & $\begin{array}{l}\text { IDHM } \\
2010\end{array}$ & Posição/UF & $\begin{array}{c}\text { IDHM } \\
1991\end{array}$ & $\begin{array}{l}\text { IDHM } \\
2000\end{array}$ & $\begin{array}{l}\text { IDHM } \\
2010\end{array}$ \\
\hline Distrito Federal & 0,616 & 0,725 & 0,824 & Tocantins & 0,369 & 0,525 & 0,699 \\
\hline São Paulo & 0,578 & 0,702 & 0,783 & Pará & 0,413 & 0,601 & 0,646 \\
\hline RioGrande do Sul & 0,542 & 0,664 & 0,746 & Amazonas & 0,430 & 0,515 & 0,674 \\
\hline Santa Catarina & 0,543 & 0,674 & 0,774 & $\begin{array}{l}\text { Rio Grande } \\
\text { doNorte }\end{array}$ & 0,428 & 0,552 & 0,684 \\
\hline Rio de Janeiro & 0,573 & 0,664 & 0,761 & Ceará & 0,405 & 0,541 & 0,682 \\
\hline Paraná & 0,507 & 0,650 & 0,749 & Bahia & 0,386 & 0,512 & 0,660 \\
\hline Goiás & 0,487 & 0,615 & 0,735 & Acre & 0,402 & 0,517 & 0,663 \\
\hline Mato Grosso do Sul & 0,488 & 0,613 & 0,729 & Pernambuco & 0,440 & 0,544 & 0,673 \\
\hline Mato Grosso & 0,449 & 0,601 & 0,725 & Sergipe & 0,408 & 0,518 & 0,665 \\
\hline Espirito Santo & 0,505 & 0,640 & 0,740 & Paraíba & 0,382 & 0,506 & 0,658 \\
\hline Minas Gerais & 0,478 & 0,624 & 0,731 & Piauí & 0,362 & 0,484 & 0,646 \\
\hline Amapá & 0,472 & 0,577 & 0,708 & Maranhão & 0,357 & 0,476 & 0,639 \\
\hline Roraima & 0,459 & 0,598 & 0,707 & Alagoas & 0,370 & 0,471 & 0,631 \\
\hline Rondônia & 0,407 & 0,537 & 0,690 & & & & \\
\hline
\end{tabular}

Adaptado de PROCRAMA DAS NAÇOEES UNIDAS PARA O DESENVOLVIMENTO (Pn ud). Atlas do de senvolwimento humano no Brasil).

Figura 13: Tabela comparativa de classificação do IDHM por unidades da federação brasileiras entre 1991, 2000 e 2010. Fonte: Editora Scipione, 2016.

Na quarta unidade, o espaço urbano e os processos de urbanização são a pauta de discussão. A explanação dos processos de urbanização parte de um contexto histórico que dá subsídio à análise geográfica. Os povos mesopotâmios são apontados como precursores dos núcleos urbanos, e, no contexto atual, são elencados os fatores atrativos e repulsivos que infuenciam os movimentos migratórios e os do êxodo rural. Os problemas advindos do intenso crescimento urbano, que tem foco as grandes e médias cidades, são trabalhados no tópico seguinte, tópico o qual descreve a segregação socioespacial que acomete as metrópoles brasileiras. Logo em seguida, há um tópico intitulado "Moradias precárias", que apresenta uma imagem de habitações fornecidas pelo governo para uma população com menor poder aquisitivo e em situação de vulnerabilidade em Cingapura (Figura 14). As capitais brasileiras, quase que em sua 
totalidade, possuem favelas em seu perímetro urbano, as que o IBGE classifica como aglomerações subnormais

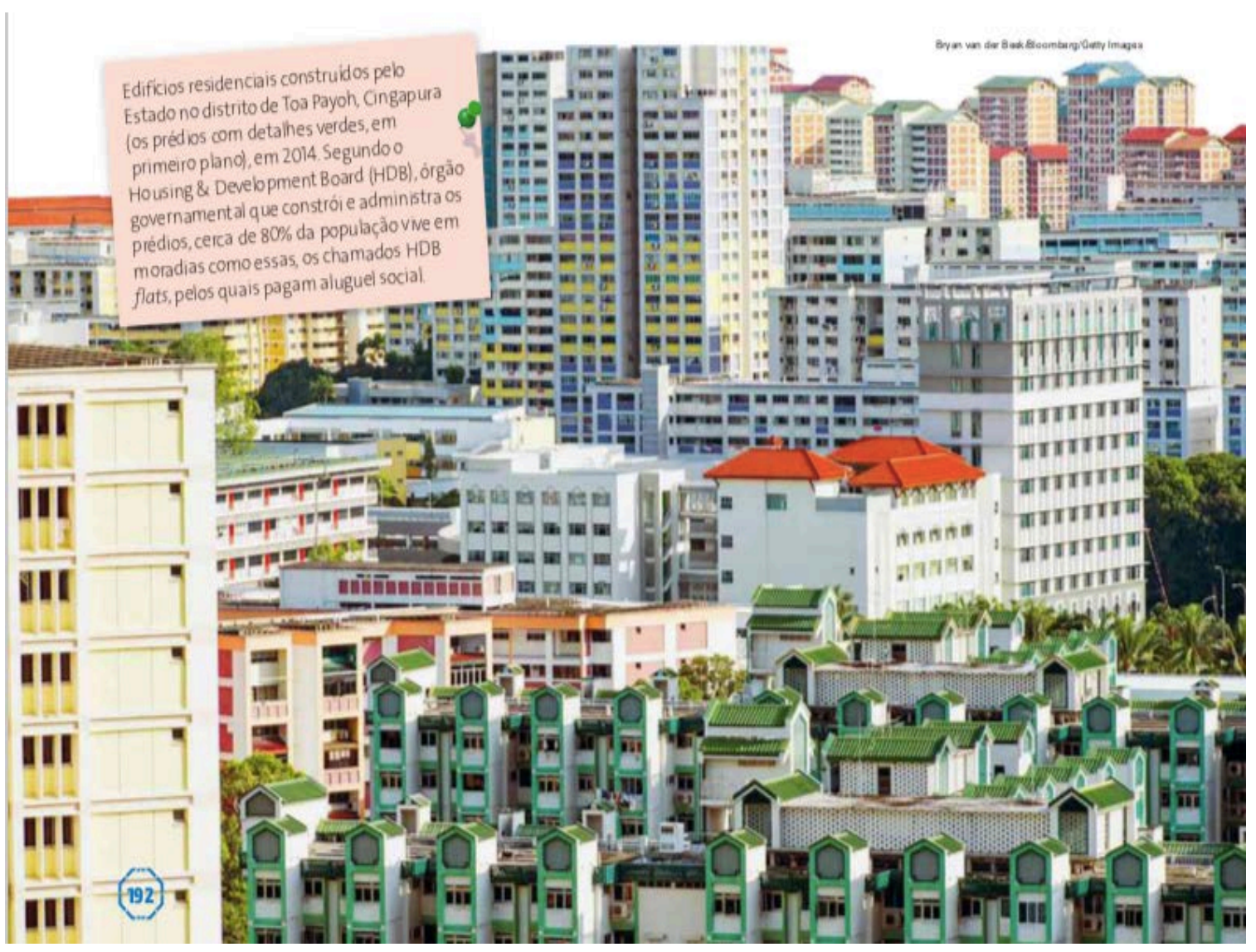

Figura 14: Representação de moradias populares em Cingapura. Fonte: Editora Scipione, 2016.

A violência urbana é ilustrada também utilizando dois gráficos, um situando o Brasil nos índices de violência contra a pessoa, e outro elencando os municípios onde ocorreram mais homicídios nas capitais brasileiras. Porém, mais uma vez, recorte étnicoracial e socioeconômico não é levado em consideração na análise. Ao apresentar a rede de hierarquia urbana, observa-se que, através da imagem inserida (Figura 15), há um esforço em apresentar um debate sobre o funcionamento da rede de serviços para determinadas classes sociais e as desigualdades na dinâmica campo-cidade. 


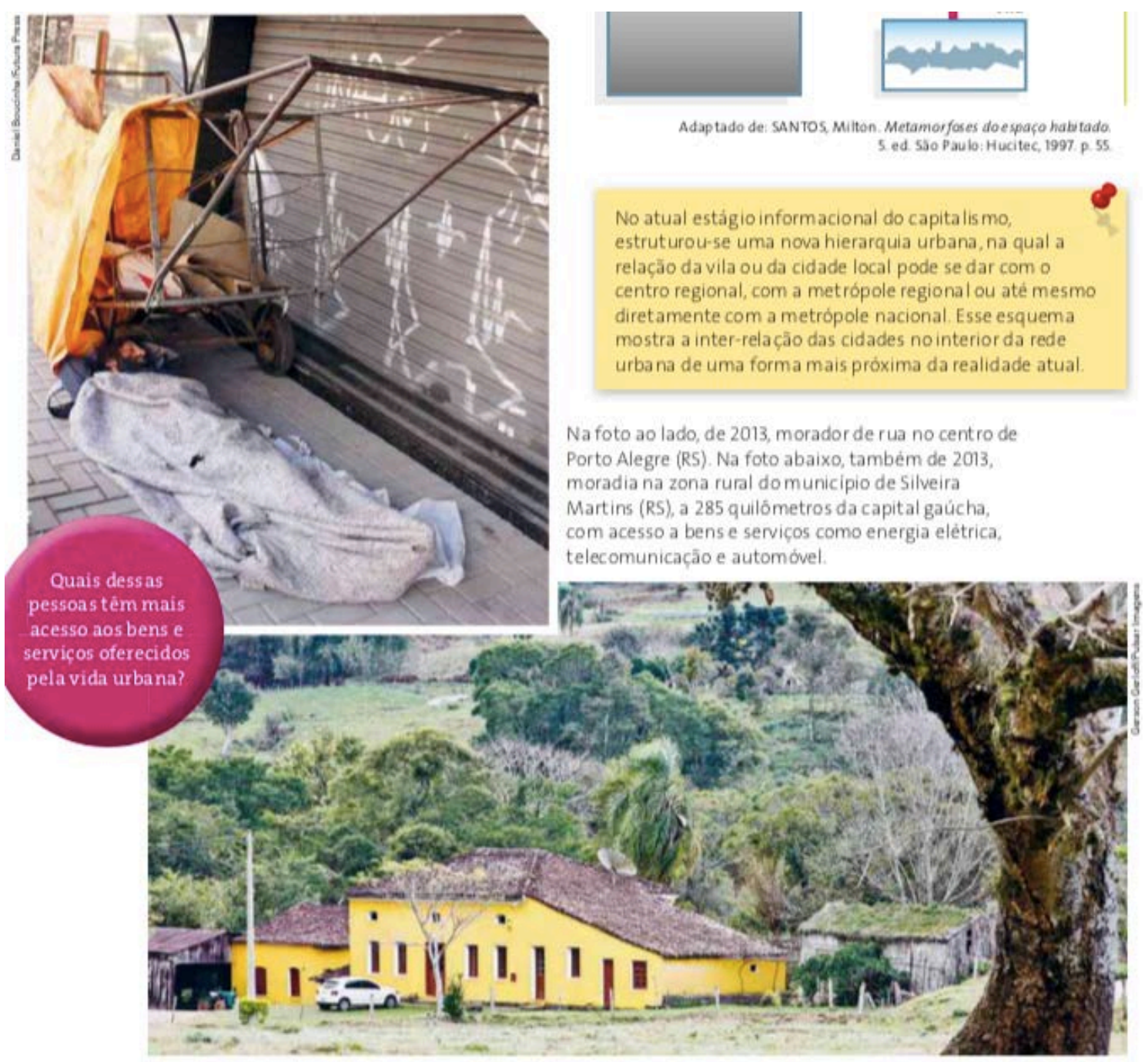

Figura 15: Representação de um contexto urbano e rural no Brasil. Fonte: Editora Scipione, 2016.

No capítulo seguinte, é apresentado o fenômeno da urbanização brasileira. O conceito de cidade, o perímetro urbano desta, e a distribuição da população é introduzida segundo o IBGE. A concentração da população na faixa litorânea é explicada a partir do processo de colonização, o qual se apoiou em determinados núcleos urbanos já existente, tais como Salvador e Recife. É apresentado também o processo de urbanização ocorrido no interior do país, nas regiões de Minas Gerais e Goiás, com a participação dos escravos, os quais representaram grande parte da população de tais áreas. Porém os aspectos da integração regional do país são tratados de forma separada, trabalhadas na seção "Para saber mais”. Tal seção trata apenas os aspectos econômicos da "integração regional”, ilustrando apenas os fluxos migratórios do país. É apresentado também um gráfico sobre a concentração de domicílios particulares permanentes adequados à moradia, porém não se desenvolve o debate étnico-racial que perpassa na discussão de tais dados. 
São apresentadas as regiões metropolitanas do Brasil e seus municípios circundantes e as relações entre os municípios pertencentes às respectivas regiões metropolitanas, bem como a hierarquia das cidades no espaço nacional. É importante observar a forma com qual o livro aborda o Estatuto da Cidade e a obrigatoriedade do Plano Diretor. É importante observar que é inserido no corpo do texto a seção “Outras leituras”, que levanta a obrigatoriedade da participação popular no processo de confecção de políticas públicas relacionadas ao ordenamento urbano, porém não há uma discussão sobre a efetiva participação e como tal ferramenta pode ser

A quinta unidade traz ao debate a questão agrária e a organização do espaço rural, na escala global e nacional. Logo no início, é inserida uma imagem (Figura 16) buscando ilustrar uma das consequências da modernização do campo, que é o êxodo rural.

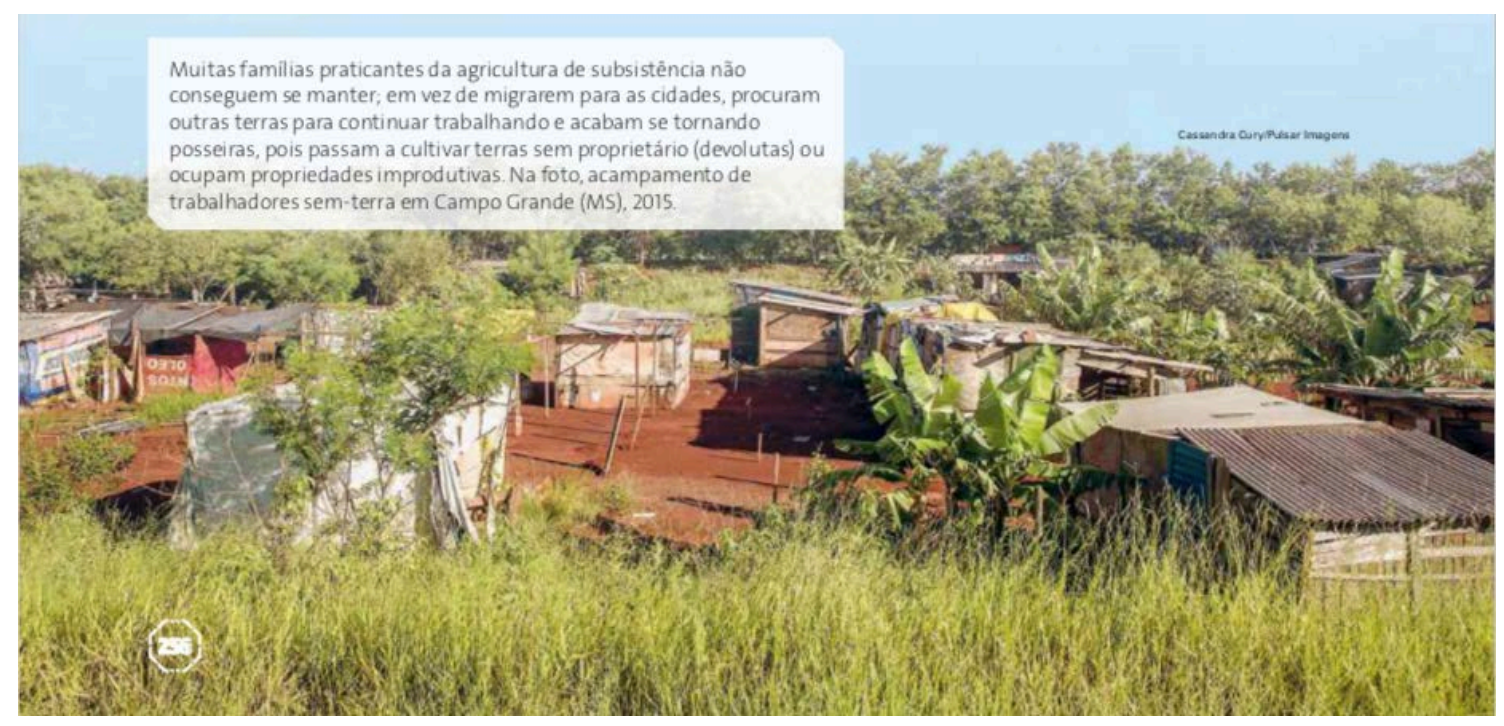

Figura 16: Representação de um acampamento de trabalhadores sem-terra em Campo Grande - MS. Fonte: Editora Scipione, 2016.

São apresentadas as modalidades de agricultura, perpassando pela agricultura familiar, agricultura de subsistência, agricultura de jardinagem e agricultura empresarial. Os autores tratam a agricultura familiar como atrasada baseada em técnicas rudimentares. A discussão do capítulo é introduzida através de duas figuras (Figura 17) que podem ser trabalhadas numa discussão que ultrapassa apenas as técnicas utilizadas nos processos agropastoris, mas que respondem à um recorte étnico-racial e socioeconômico. 


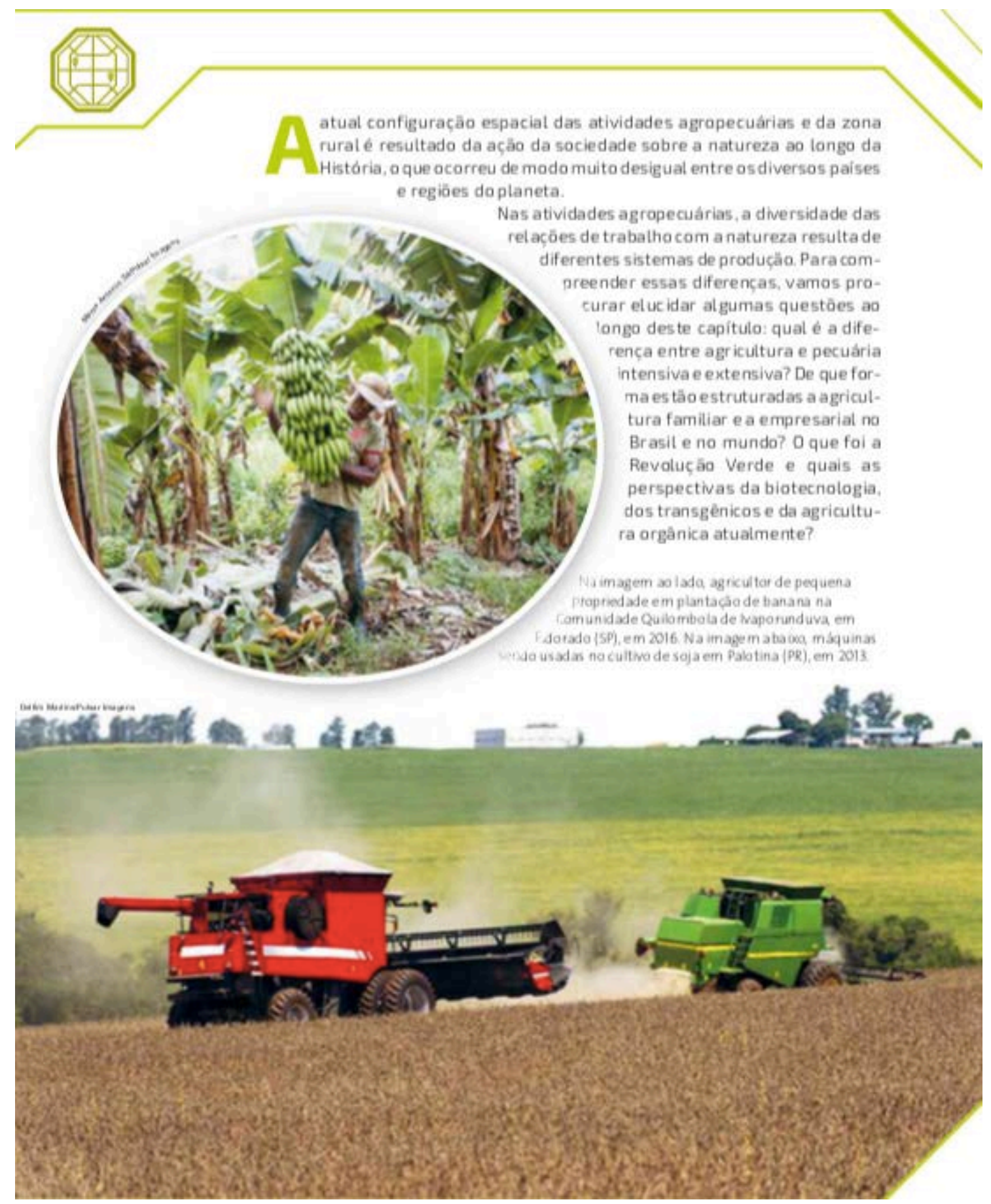

Figura 17: Representação de diferentes modalidades da agricultura. Fonte: Editora Scipione, 2016.

Ao apresentar a Revolução Verde, nota-se que a unidade não possui uma preocupação em estender o debate aos desdobramentos sociais da problemática advinda das alterações do trabalho campesino. No tópico “A população rural e o trabalhador agrícola”, não há o cuidado em se realizar um recorte étnico-racial, global ou nacional, relativo. 
A discussão logo passa para uma discussão sobre biotecnologia e alimentos transgênicos, sem se utilizar do recorte étnico-racial. A agricultura orgânica é introduzida logo em seguida, mas não há um dado que demonstre que os maiores responsáveis pela agricultura orgânica estão inseridos num contexto de agricultura familiar

Logo em seguida, ao se apresentar o panorama da agropecuária brasileira, são utilizadas algumas informações apresentadas anteriormente. Chama atenção a discussão e fatores de repulsão do território agrícola que acabam por provocar o movimento de migração em direção às cidades, o anteriormente nomeado êxodo rural. É apresentado, no corpo do texto, a existência do Estatuto da Terra e os movimentos de reforma agrária, porém não há uma discussão de tais temas, sendo esses apenas pincelados. É interessante observar nesta unidade a distribuição espacial dos movimentos agropecuários existentes no território brasileiro. Porém, mais uma vez, tais tópicos não são acompanhados por uma discussão socioeconômica, ou ainda, étnico-racial, dos fenômenos que explicam a distribuição espacial da atividade agropecuária no território brasileiro.

\section{CONCLUSÕES E RECOMENDAÇÕES}

Após uma análise e discussão sobre os temas abordados no livro didático, podese concluir que o livro carece de uma discussão que se utilize de um recorte étnico-racial e socioeconômico para construir, de fato, uma análise crítica. Segundo a PDAD de 2019, cerca de 54\% da população brasileira se autodeclara preta ou parda, portanto, um debate que insira o contexto histórico e social dessa parcela da população é de extrema importância.

Numa tentativa de superar um apagamento do contexto afrodescendente no Brasil, a Lei 10.639, de 9 de janeiro de 2003, a qual promulga a obrigatoriedade da inserção das relações étnico-raciais e do ensino de história e cultura afro-brasileira e africana no currículo nacional. Essa ferramenta jurídica é de suma importância, visto que o livro didático é um dos elementos que compõem a estrutura curricular nacional e é atravessado por diversos processos, sendo fruto uma política de Estado (Santos, 2018).

Analisar de que forma um livro didático apresenta o contexto histórico e étnicoracial de uma maior parte da população é importante para compreender de que forma os 
elementos que subsidiam a construção de um pensamento crítico por parte dos alunos. Ao observar que os debates inseridos no livro não estão atravessados por uma discussão étnico-racial e que se preza mais por contextos e informações mais genéricas e com um viés mais econômico, questiona-se a posição dos autores, os quais afirmam que buscam promover uma contextualização do território, compreendendo este como um espaço produzido e apropriado pelas sociedades humanas. Porém alguns estratos sociais possuem um maior espaço sobre esse processo de produção e apropriação em detrimentos de outros. Questiona-se o espaço dado para a o estrato social que representa a maior parte da população brasileira. Algumas fotografias inseridas durante a publicação não encontramse situadas em uma discussão que leve em consideração os fatores socioeconômicos e/ou étnico-raciais, e por vezes acabam por reproduzir algumas leituras racistas e errôneas sobre algumas situações, vide a Figura 9, que traz informações erradas sobre países, suas bandeiras nacionais e suas seleções na Copa dos Refugiados de 2014.

Como forma de superar tal afastamento da discussão, a inserção de discussões étnico-raciais, se utilizando de dados estatísticos e contextualizações históricas, em temáticas tais como a produção de energia no Brasil, as motivações dos fluxos migratórios, a população economicamente ativa e os problemas sociais urbanos.

A inserção do debate racial no livro ocorre de formas sutis, por vezes se utilizando de seções específicas fora do corpo do texto. Questiona-se o por que de não se inserir o debate nos próprios tópicos e capítulos do texto ao invés de separar tal debate, igualando a importância do debate étnico-racial, que pode ser discutido numa ótica geográfica ao invés de utilizar textos de outras áreas do conhecimento.

Se utilizar dos dados inseridos e realmente interpretá-los, trazendo uma discussão histórica e étnico-racial adequada à realidade nacional seria a melhor forma de construir um livro que fosse, de fato, acessível à todas as realidades brasileiras. Os recursos iconográficos devem ser situados nesse mesmo contexto socioeconômico e étnico-racial, para evitar uma interpretação racista e degradante para as realidades apresentadas. Não situar a questão da população afro-brasileira num país cuja população negra e parda é maioria, torna o livro um instrumento que não atende à discussão que a Lei 10.639, de 9 de janeiro de 2003, a qual pretende inserir o debate racial para uma verdadeira compreensão do espaço geográfico brasileiro, espaço este que abriga tensões e contradições. É delicado apontar o uso da Geografia Crítica na metodologia do livro, mas 
não explorar uma leitura de fato crítica das nuances desse espaço tensionado e contraditório, pois a simples apresentação de dados e imagens, deslocados de sua realidade e de todas as nuances que atravessam o fenômeno observado é perpetuar uma leitura rasa e acrítica do espaço.

\section{REFERÊNCIAS BIBLOGRÁFICAS}

BAIRRO, C. C. de. Livro didático: um olhar nas entrelinhas da sua história.

Disponível em:

http://www.histedbr.fe.unicamp.br/acer_histedbr/seminario/seminario8/

_files/Cj5GgE6L.doc; Acesso em 19 de março de 2021;

CAMPOS, Helcio Ribeiro. Considerações sobre ideologias presentes na Geografia Crítica. CSOnline - Revista Eletrônica de Ciências Sociais, ano 6, ed. 14, jan./abr. 2012;

HOOKS, Bell. Mulheres negras: moldando a teoria feminista. Revista Brasileira de Ciência Política, nº16. Brasília, janeiro - abril de 2015;

MANTOVANI, Flávia. Haiti vence Copa de refugiados; sírios seguem Ramadã e não tomam água. G1. 29 de jun. 2014. Disponível em:

http://g1.globo.com/sao-paulo/noticia/2014/06/na-copa-dos-refugiados-haiti-vencesiria-segue-o-ramada-e-fica-em-ultimo.html . Acesso em 20 de março de 2021;

MARQUES, Roberto. Qual o lugar do livro didático na reforma do Ensino Médio? In: TONINI, Ivaine Maria et.al. (orgs.). Geografia e livro didático para tecer leituras de mundo. São Leopoldo: Oikos, 2018;

MEC/SECADI. Plano nacional de implementação das diretrizes curriculares nacionais para educação das relações étnico-raciais e para o ensino de história e cultura afrobrasileira e africana. Ministério da Educação, Secretaria de Educação Continuada, Alfabetização, Diversidade e Inclusão. Brasília, 2013; 
PAULO, Paula Paiva. Construção de hidrelétrica é ameaça para comunidade kalunga que vive há 300 anos no maior quilombo do Brasil. Geledes. 31 de out. 2019. Disponível em:

https://www.geledes.org.br/construcao-de-hidreletrica-e-ameaca-para-comunidadekalunga-que-vive-ha-300-anos-no-maior-quilombo-do-brasil/ . Acesso em 20 de março de 2021;

SANTOS, Renato Emerson. A Lei 10.639 no PNLD de Geografia: um ensaio sobre questões, mudanças e permanências. TONINI, Ivaine Maria et.al. (orgs.). Geografia e livro didático para tecer leituras de mundo. São Leopoldo: Oikos, 2018. 